\title{
EL AGUJERO DEL CALCETÍN
}

Me he puesto tantas veces calcetines con agujeros que llegué a pensar que los fabricaban ya con los huecos, pero los ejercicios de contemplación, antes de ponérmelos, en mi mano, como si algo me dijeran, ya puestos, mudos, me hizo ver que no, que no hay posibilidades de hacerlos en serie.

$$
* * *
$$

Nunca nos ponemos un calcetín con el mismo agujero.

(Heráclito)

$$
* * *
$$

Los agujeros son como heridas viejas, que han dejado de sangrar pero que no cicatrizan, fósiles del dolor que baja por las venas y se fuga -allí en donde los calcetines se han vuelto parte del cuerpo.

$$
* * *
$$

El calcetín tiene esquemas de comportamiento: el dedal es parte de la historia y el presente es el dedo gordo.

$$
* * *
$$

Un agujero en el dedo chiquito es una anomalía, pero no despierta ternura sino tristeza, o más bien: amargura. A la pequeñez se suma lo pequeño: detestable sombra de Pulgarcito. 
Se lee el pozo del café y el fondo del iris. ¿Por qué no el agujero del calcetín? Porque siempre tiene algo de pequeña tragedia, de desastre por venir e irremediable, ya ocurrió antes de suceder.

$$
* * *
$$

El calcetín se descose y -ahora, hoy-ya no admite remiendo. Nunca podría ser el trabajo de Penélope.

$$
* * *
$$

El pie escapa a sus orígenes: huye de sí mismo en cada paso, pero no alcanza nunca -algo se ha perdido- la dignidad de la huella. 
La reproducción total o parcial de este artículo se podrá hacer si el ITAM otorga la autorización previamente por escrito. 